\title{
Mechanisms of cellular adaptation to quantum dots - the role of glutathione and transcription factor EB
}

\section{Kevin D. Neibert \& Dusica Maysinger}

To cite this article: Kevin D. Neibert \& Dusica Maysinger (2012) Mechanisms of cellular adaptation to quantum dots - the role of glutathione and transcription factor EB, Nanotoxicology, 6:3, 249-262, DOI: 10.3109/17435390.2011.572195

To link to this article: http://dx.doi.org/10.3109/17435390.2011.572195

+ View supplementary material $\widetilde{ }$

曲 Published online: 17 Apr 2011.

Submit your article to this journal $\pi$

Џ Article views: 290

Q View related articles ¿ 


\title{
Mechanisms of cellular adaptation to quantum dots - the role of glutathione and transcription factor EB
}

\author{
KEVIN D. NEIBERT \& DUSICA MAYSINGER \\ Department of Pharmacology and Therapeutics, McGill University, Montreal, Québec, Canada
}

(Received 10 December 2010; accepted 11 March 2011)

\begin{abstract}
Cellular adaptation is the dynamic response of a cell to adverse changes in its intra/extra cellular environment. The aims of this study were to investigate the role of: (i) the glutathione antioxidant system, and (ii) the transcription factor EB (TFEB), a newly revealed master regulator of lysosome biogenesis, in cellular adaptation to nanoparticle-induced oxidative stress. Intracellular concentrations of glutathione species and activation of TFEB were assessed in rat pheochromocytoma (PC12) cells following treatment with uncapped CdTe quantum dots (QDs), using biochemical, live cell fluorescence and immunocytochemical techniques. Exposure to toxic concentrations of QDs resulted in a significant enhancement of intracellular glutathione concentrations, redistribution of glutathione species and a progressive translocation and activation of TFEB. These changes were associated with an enlargement of the cellular lysosomal compartment. Together, these processes appear to have an adaptive character, and thereby participate in the adaptive cellular response to toxic nanoparticles.
\end{abstract}

Keywords: Adaptation, glutathione, quantum dots, transcription factor EB (TFEB)

\section{Introduction}

Nanoparticles (NPs) are continuously being developed for a diverse range of applications in the rapidly growing field of nanomedicine, primarily as imaging, diagnostic and therapeutic tools. However, many of the interactions between nanoparticles and biological systems, as well as related mechanisms of nanoparticleinduced toxicity, remain unclear ( $\mathrm{Nel}$ et al. 2006, 2009; Maysinger 2007). The cellular response to nanoparticle exposure has been shown to be dependent on physicochemical properties such as size, shape, core composition, surface coating, ligand arrangement and charge (Jiang et al. 2008; Verma and Stellacci 2009).

Capped quantum dots (QDs) are highly florescent and photostable NPs, making them suitable candidates for in vivo imaging and for highly sensitive ex vivo diagnostic assays (Kosaka et al. 2010). The capping of QDs with a zinc sulfide ( $\mathrm{ZnS}$ ) shell increases core stability and allows further modification of surface chemistry, providing the potential for diverse sitedirected targeting and enhanced biocompatibility. First-generation uncapped or 'naked' cadmium telluride $(\mathrm{CdTe})$ and cadmium selenide $(\mathrm{CdSe}) \mathrm{QDs}$ are cytotoxic in several cell systems (Lovric et al. 2005a; Lovric et. al 2005b; Choi et al. 2007; Maysinger 2007). QD-induced cell death involves the release of free cadmium ions from the QD core, formation of reactive oxygen species and nitrogen species (ROS/RNS), and the disruption of cellular redox homeostasis (Choi et al. 2007). Exposure to both artificial and biological NPs can lead to the disruption of cellular redox status and activation of compensatory mechanisms. However, when exposed to toxic nanomaterials for a short time or in low nanomolar concentrations, cells can successfully adapt by engaging antioxidant defenses and lipid re-distribution processes (Jain et al. 2009; Khatchadourian and Maysinger 2009). Specific mechanisms that mediate these adaptive cellular processes remain unclear.

Throughout evolution, eukaryotic cells have developed several overlapping defense mechanisms that become activated in response to varying degrees of oxidative stress (Janssen-Heininger et al. 2008). The generation of oxidative stress involves the uncompensated accumulation of both ROS and RNS leading to the formation of harmful adducts with cellular proteins, lipids and DNA (Li et al. 2008). ROS/RNS

Correspondence: Dr Dusica Maysinger, Department of Pharmacology \& Therapeutics, McGill University, 3655 Promenade Sir-William-Osler, McIntyre Medical Sciences Building, Room 1314, Montreal, QC, H3G 1Y6, Canada. Tel: +1 514398 1264. Fax: +1 514 398 6690. E-mail: dusica.maysinger@mcgill.ca 
molecules function as both oxidants and signaling molecules through alterations in cellular redox homeostasis and the targeting of redox sensitive cysteine residues (D'Autreaux and Toledano 2007). Cell specific responses to oxidative stress have been shown to be dependent on subtle inter-population variations in cell size, adenosine triphosphate (ATP) concentration and plasma membrane composition (Simakova and Arispe 2007). The capacity of cells to adapt to changes in cellular homeostasis may also depend on its endogenous antioxidant status which is determined by the content of antioxidant enzymes such as superoxide dismutase (SOD) and catalase (CAT) as well as small molecular antioxidant molecules such as ascorbic acid, tocopherol, thioredoxin and glutathione (DinkovaKostova and Talalay 2008).

Glutathione is considered to be a key regulator of the cellular redox homeostasis due to its low redox potential $(-240 \mathrm{mV}$ at $\mathrm{pH} 7.0)$, high intracellular abundance (1-13 $\mathrm{mM})$ and ubiquitous expression in eukaryotic cells. Reduced glutathione (GSH) reacts primarily with $\mathrm{H}_{2} \mathrm{O}_{2}$ resulting in the formation of oxidized glutathione (GSSG) and $\mathrm{H}_{2} \mathrm{O}$. De novo synthesis of glutathione by gamma-glutamylcysteine synthetase (GCL), the rate limiting step, can be enhanced by increasing the intracellular cysteine pool via the addition of thiol-containing antioxidant molecules such as $\mathrm{N}$-acetylcysteine (NAC) and lipoic acid (LA) (Ruffmann and Wendel 1991; Packer et al. 1995). Healthy, unstressed cells maintain a high intracellular GSH/GSSG ratio to ensure the availability of GSH. As cells become increasingly stressed, the GSH/GSSG ratio decreases which results in the transcriptional activation of the antioxidant response element (ARE) by the NF-E2-related factor 2 (Nrf2) transcription factor, and expression of antioxidant genes such as CAT, SOD and GCL (Biswas and Rahman 2008). Nrf2 translocation to the nucleus is tightly controlled by stress responsive mitogen-activated protein kinases (MAPKs) following disruption of cellular redox homeostasis (Maher and Yamamoto 2010). Indeed, activation of Nrf2 in response to GSH depletion is an important determinant of cellular fate ( $\mathrm{Li}$ et al. 2007). Dynamic changes in the lysosomal compartment following oxidative stress are also believed to play a role in the cellular adaptation process (Khatchadourian and Maysinger 2009).

The coordinated transcriptional behaviour of lysosomal genes was recently revealed to be dependent on transcription factors of the microphthalamiatranscription factor E (MiT/TFE) subfamily of basic helix-loop-helix leucine zippers (bHLHZIP). Overexpression of one member of this family, transcription factor EB (TFEB), was shown to significantly increase the expression of lysosomal genes and enhance the activity of lysosomal enzymes by directly binding to the CLEAR (coordinated lysosomal expression and regulation) element (Sardiello et al. 2009). The protein product of one of these genes, lysosomal-associated membrane protein 1 (LAMP1), plays a key role in lysosome biogenesis, stability and function (Eskelinen 2006). Recent studies have shown that most QDs tend to accumulate in lysosomal compartments and may themselves induce lysosome formation (Behrendt et al. 2009; Khatchadourian and Maysinger 2009; Przybytkowski et al. 2009). Our hypothesis is that activation of TFEB drives many of the observed changes in the cellular lysosomal compartment in response to QDinduced oxidative stress. Understanding the mechanisms involved in the adaptation process may lead to the development of strategies that enhance intrinsic cellular defenses for the purpose of limiting and/or circumventing nanoparticle-induced toxicity.

\section{Methods}

\section{Cell culture and media}

Undifferentiated rat pheochromocytoma cells (PC12) acquired from ATCC (CRL-1721) were cultured in RPMI 1640 media (Gibco) containing 5\% fetal bovine serum (Gibco), 1\% penicillin-streptomycin (Gibco) and free of phenol-red. Cells were cultured in T75 cell culture flasks (Sarstedt) and maintained at $37^{\circ} \mathrm{C}, 5 \% \mathrm{CO}_{2}$ in a humidified atmosphere. The seeding density was 40,000 cells per well in 96-well plates (Sarstedt), 400,000 cells per well in sixwell plates (Sarstedt), and 10,000 cells per well in eight-well chambers slides (Lab-Tek), where indicated. Following seeding, PC12 cells were grown for $24 \mathrm{~h}$ to attain confluency prior to cell treatments.

\section{Cell treatments}

Cells were washed twice with PBS (Gibco) before and after all cell treatments. Cell treatments were added in serum free medium and incubated at $37^{\circ} \mathrm{C}$ for the times indicated. In experiments involving lipoic acid (200 $\mu \mathrm{M}$; Sigma), cells were pretreated in serum containing media for $24 \mathrm{~h}$. In experiments involving L-buthionine-sulfoximine (50 $\mu \mathrm{M}$; Sigma), cells were pretreated in serum containing media for $4 \mathrm{~h}$.

\section{Nanoparticle preparation and characterization}

Poly(caprolactone)-b-poly(ethylene oxide) NPs were synthesized and characterized according to previous studies (Savic et al. 2003). Gold nanoparticle containing micelles were prepared as described in detail (Sidorov et al. 2004; Soo et al. 2007). CdSe/ZnS, $\mathrm{CdSe} / \mathrm{ZnS} / \mathrm{PEG}$ and uncapped CdTe NPs were 
synthesized and characterized as per the method described previously (Gaponik et al. 2002), and characterization was performed as described in our previous studies (Lovric et al. 2005a ; Cho et al. 2007; Choi et al. 2007). A summary of nanoparticle composition, size, surface coating and concentrations used is provided in Table I.

\section{Flame atomic absorption}

The cadmium content of CdTe and CdSe/ZnS QDs (4, 20 and $40 \mathrm{nM}$ ) was measured using a PerkinElmer 3030 atomic absorption spectrometer. The instrument was operated in background correction mode. Detection of cadmium in $3 \mathrm{~mL}$ sample aliquots was carried out at room temperature using a hollow cathode lamp cadmium lamp (UNICAM) at a wavelength of $228.8 \mathrm{~nm}$ ( $4 \mathrm{~mA}$ current, 48 energy). The calibration fits were obtained using standard solutions of cadmium (SCP Science) ranging from 0-15 mg/L.

\section{Alamar Blue assay}

To assess relative metabolic activity, cells were seeded in 96-well plates and incubated with $10 \mu \mathrm{L}$ Alamar Blue (Invitrogen, CA, USA) diluted with $90 \mu \mathrm{L}$ serum free media $(10 \% \mathrm{vol} / \mathrm{vol})$ per well for $1 \mathrm{~h}$ at $37^{\circ} \mathrm{C}$ following exposure to NPs (4, 20, 40 and $250 \mathrm{nM}$; $24 \mathrm{~h}$ ). Mean fluorescent intensity was measured with a FLUOROstar Optima fluorimeter (BGM, Labtech) with filters were set to $\mathrm{Ex} / \mathrm{Em}=544 / 590 \mathrm{~nm}$ and employed $3 \times 3$ matrix well scanning.

\section{GSH, GSSH and total glutathione assay}

Reduced glutathione (GSH), oxidized glutathione (GSSG) and total glutathione (tGSH) concentrations were determined biochemically (Calbiochem Kit) based on the Tietze method which measures the reaction of DTNB (5,5'-dithio-bis-2-nitrobenzoic acid) with the sulfhydryl group of GSH to produce yellow colored 5-thio-2-nitrobenzoic acid (TNB) (Tietze 1969). Cells were seeded in six-well plates and exposed to NPs (4, 20, 40, $250 \mathrm{nM} ; 24 \mathrm{~h}$ ). Following treatment, cells were detached with $0.05 \%$ trypsin/EDTA (Gibco) for $5 \mathrm{~min}$ at $37^{\circ} \mathrm{C}$, spun down at $3000 \mathrm{rpm}$ for $5 \mathrm{~min}$ and resuspended in $1 \mathrm{~mL}$ of fresh serum free media. Sample aliquots $(90 \mu \mathrm{L})$ were added to trypan blue (Gibco) $(10 \mu \mathrm{L})$ and viable cells were counted with a hemocytometer (Fisher). The remaining cells were pelleted down, resuspended in assay buffer $(1 \mathrm{~mL})$, lysed by freeze/ thaw ( $5 \mathrm{~min}$ at $-80^{\circ} \mathrm{C}$ and $5 \mathrm{~min}$ at $37^{\circ} \mathrm{C}$ ), spun down at $10,000 \mathrm{rpm}$ for $10 \mathrm{~min}$ and incubated with DTNB $(0.5 \mathrm{mM})$ for $30 \mathrm{~min}$ at room temperature. The absorbance of TNB (412 nm) was measured in sample aliquots $(100 \mu \mathrm{L})$ with a bench-top microplate reader (BIORAD).

\section{Intracellular glutathione imaging}

GSH reacts specifically with monochlorobimane (mCBi; Cayman), a non-fluorescent membrane permeable dye, to form a fluorescent adduct (mCBiGSH). Cells were seeded in 96-well plates and exposed to CdTe QDs (20, $40 \mathrm{nM} ; 24 \mathrm{~h}$ ) then incubated with $\mathrm{mCBi}(50 \mu \mathrm{M})$ for $1 \mathrm{~h}$ at $37^{\circ} \mathrm{C}$. Dye containing media was aspirated and cells were washed with PBS. Fresh serum free media was added prior to live cell imaging. Fluorescence images were acquired with a Leica DFC350FX monochrome digital camera connected to a Leica DMI4000B inverted fluorescence microscope. The fluorescent intensity of the mCBI-GSH adduct was quantified and individual cells were classified as containing high, med or low levels of intracellular

Table I. Cytotoxicity of selected nanoparticles.

\begin{tabular}{|c|c|c|c|c|}
\hline Nano-sized particle & Size $(\mathrm{nm})$ & Surface coating & Concentration (nM) & Cell viability (\%) \\
\hline PCL-b-PEO & 25 & PEO & $250^{\mathrm{a}}$ & $97.6 \pm 5.1$ \\
\hline $\mathrm{P}_{4 \mathrm{VP}}{ }_{21}$-b-PEO 45 -gold nanoparticle & 24 & PEO & $250^{\mathrm{a}}$ & $96.1 \pm 9.0$ \\
\hline \multirow[t]{4}{*}{ CdTe QD } & 4 & Cysteamine & 250 & $7.7 \pm 4.3^{\star \star \star}$ \\
\hline & & & 40 & $30.1 \pm 9.7^{\star \star \star}$ \\
\hline & & & 20 & $64.6 \pm 7.1^{\star \star \star}$ \\
\hline & & & 4 & $95.1 \pm 8.3$ \\
\hline CdSe/ZnS QD & 10 & Cysteamine & $250^{\mathrm{a}}$ & $95.3 \pm 4.4$ \\
\hline CdSe/ZnS/PEG QD & $25-30$ & PEG & $250^{\mathrm{a}}$ & $95.7 \pm 3.9$ \\
\hline
\end{tabular}

Cellular viability was assessed in cells exposed to nanoparticles (4, 20, 40 and $250 \mathrm{nM} ; 24$ hours). Data are presented as means \pm SEM of three individual experiments of triplicates. Significance was tested with independent $t$-tests (with Bonferroni correction) and indicated by

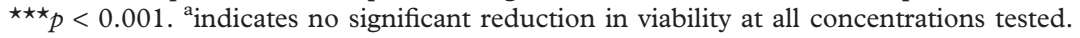


glutathione (tGSH) following image analysis using ImageJ (low $<1000$ a.u.; medium $1000<2000$ a.u. and high $>2000$ a.u.). The number of cells in each subpopulation was normalized by the total number of cells per frame. At least nine individual pictures were used per condition for quantification. Additionally, the fluorescent intensity of the mCBi-GSH adduct was measured with a FLUOROstar Optima fluorimeter (BGM, Labtech). Filters were set to $\mathrm{Ex} / \mathrm{Em}=380 /$ $460 \mathrm{~nm}$ and employed $3 \times 3$ matrix well scanning.

\section{Detection of Reactive Oxygen Species (ROS)}

ROS generation was measured using dihydroethidium (DHE; Molecular Probes). Cells were seeded in six-well plates and treated with CdTe QDs $(20 \mathrm{nM}$; $4 \mathrm{~h})$ then incubated with DHE $(10 \mu \mathrm{M})$ in the dark for $30 \mathrm{~min}$. The conversion of DHE into highly fluorescent ethidium bromide was measured spectrofluoremetrically with a FLUOROstar Optima fluorimeter (BGM, Labtech) with filters set to $\mathrm{Ex} /$ $\mathrm{Em}=544 / 612 \mathrm{~nm}$ and employed $3 \times 3$ matrix well scanning.

\section{Detection of Reactive Nitrogen Species (RNS)}

RNS generation was assessed by measuring 3-nitrotyrosine (3NT), a product of tyrosine nitration. Cells were seeded in eight-well chamber slides and treated with CdTe QDs (20 nM; $24 \mathrm{~h}$ ) then fixed with $4 \%$ paraformaldehyde (BDH laboratory), permeabilized with $0.1 \%$ Triton-X 100 (Amersham) and subsequently blocked with $10 \%$ goat serum (GS; Sigma). Immunostaining was performed using primary $3 \mathrm{NT}$ antibody (Millipore) diluted 1:1000 in GS and incubated overnight at $4^{\circ} \mathrm{C}$. The next day, cells were washed with PBS and incubated Alexa 594 goat anti-rabbit IgGconjugated secondary antibody (Molecular probes) diluted 1:1000 in 10\% GS for $1 \mathrm{~h}$ at room temperature. Cells were washed with PBS and then counterstained with $10 \mu \mathrm{M}$ Hoechst 33258 (Invitrogen) for $60 \mathrm{~min}$. Stained coverslips were mounted onto microscope slides (Super Frost) using Aqua PolyMount (Polyscience). Fluorescence images were acquired with a Leica DFC350FX monochrome digital camera connected to a Leica DMI4000B inverted fluorescence microscope.

\section{Western blotting}

Cells were seeded in six-well plates and treated with CdTe QDs (20 nM; $24 \mathrm{~h}$ ) and washed twice with icecold PBS, lysed in Nonident P-40 buffer [50 mM Tris$\mathrm{HCl}(\mathrm{pH} 8.0$ ), $1.37 \mathrm{mM} \mathrm{NaCl}, 1 \%$ (vol/vol) Nonidet
P-40, 10\% (vol/vol) glycerol, $0.1 \mathrm{mM}$ sodium orthovanadate, complete protease inhibitor cocktail tablet (Roche)] and subjected to standard protein separation using $12 \%$ SDS-PAGE minigels. Membranes were then probed with non-fat dry milk. Blocked membranes were then probed with primary antibodies. Anti-phospho-JNK (Promega) was used at a 1:5000 dilution. Anti-JNK1 (Santa Cruz Biotechnology) was used at a dilution of 1:1000. Anti-phosphop38 was used at a dilution of 1:5000 (Promega). Antip38 was used at a dilution of 1:1000 (Santa Cruz Biotechnology). Anti-actin was used at a 1:1000 dilution (Chemicon). Horseradish peroxidase-labeled antibodies (1:4000, Amersham) were used as secondary antibodies. Immunoblots were developed using the enhanced chemiluminescence system (Amersham) and X-OMAT film (Kodak).

\section{Transmission Electron Microscopy (TEM)}

Cells were seeded in eight-well EM chamber slides (Lab-Tek) and treated with CdTe QDs (20 nM, $24 \mathrm{~h}$ ). Following treatment, cells were fixed with $2.5 \%$ gluteraldehyde in $0.1 \mathrm{M}$ sodium cacodylate buffer and post-fixed with $1 \%$ osmium tetroxide $\left(\mathrm{OsO}_{4}\right)$ in a $1.5 \%$ potassium ferrocyanide $(\mathrm{KFeCN})$ solution. Thin sections $(0.1 \mu \mathrm{m})$ were prepared using an Ultracut-E ultramicrotome (Leica Microsystems), and digital images were taken with a Gatan 792 Bioscan $1 \mathrm{k} \times 1 \mathrm{k}$ Wide Angle Multiscan CCD camera (JEM-2000 FX).

\section{LysoTracker DND-26 staining}

The total lysosomal content of live PC12 cells was measured using LysoTracker DND-26 (Invitrogen). Cells were seeded in eight-well chamber slides and treated with rapamycin (Sigma; $200 \mathrm{nM}$ ) and CdTe QDs $(20 \mathrm{nM})$ for 1,6 and $24 \mathrm{~h}$, then incubated with Hoechst $33258(10 \mu \mathrm{M})$ for $60 \mathrm{~min}$ and LysoTracker Green DND-26 (500 nM) for $2 \mathrm{~min}$. Fluorescence images were acquired with a Leica DFC350FX monochrome digital camera connected to a Leica DMI4000B inverted fluorescence microscope. Total lysosomal content was then quantified using ImageJ imaging software.

\section{Assessment of TFEB translocation}

Cells were seeded in eight-well chamber slides and treated with rapamycin $(200 \mathrm{nM})$ and CdTe QDs $(20 \mathrm{nM})$ for 1,6 and $24 \mathrm{~h}$. Following treatment, immunostaining was performed using primary TFEB antibody (Millipore) diluted 1:1000 in GS and 
incubated overnight at $4^{\circ} \mathrm{C}$. Fluorescence images were acquired with a Leica DFC350FX monochrome digital camera connected to a Leica DMI4000B inverted fluorescence microscope. TFEB translocation was then quantified using ImageJ imaging software.

\section{Statistical analysis}

Statistical significance was analyzed using SYSTAT 10 (SPSS) and determined by analysis of variance (ANOVA) followed by post hoc Dunnett's test or by independent $t$-test (where specified). Differences were considered significant where ${ }^{\star} p<0.05$, ${ }^{\star \star} p<0.01$ and ${ }^{\star \star \star} p<0.001$.

\section{Results}

Changes in intracellular glutathione species in cells exposed to toxic nanoparticles.

To investigate the adaptive cellular response to nanoparticle-induced stress, we first assessed PC12 cell viability following exposure $(0-250 \mathrm{nM})$ to a diverse range of NPs with varied composition and size (Table I). Poly( $\epsilon$-caprolactone)- poly(ethylene oxide) (PCL-b-PEO) block copolymer micelles are watersoluble biocompatible nanocontainers used as a drug delivery system (DDS) for hydrophobic drugs (Savic et al. 2003). Poly(4-vinylpyridine)-block-poly (ethylene oxide) (P4VP21-b-PEO45) micelles containing gold nanoparticle were developed to enhance the visualization of micelles in subcellular compartments, including lysosomes (Soo et al. 2007). Several types of QDs were selected for this study including: Uncapped (poorly stable) CdTe QDs, capped (stable) CdSe/ZnS QDs and poly ethylene glycol (PEG) conjugated (highly stable) CdSe/ZnS/PEG QDs (Lovric et al. 2005a, 2005b; Choi et al. 2007, 2008). Uncapped QDs readily leak core components (cadmium and tellurium) and are more prone to aggregation (Pelley et al. 2009). The cadmium content of uncapped CdTe QDs and capped $\mathrm{CdSe} / \mathrm{ZnS}$ QDs was determined using flame atomic absorption (FAA). CdTe QDs samples contained $5 \times$ more cadmium than CdSe/ZnS QDs at equimolar concentrations (Supplementary Figure 1, available online). These results show a significant shedding of cadmium from the core of the uncapped QDs. The aggregation status of CdTe QDs was determined using dynamic light scattering (DLS). Results from these analyses show that CdTe QDs formed large aggregates (Supplementary Figure 2, available online). QDs capped with a ZnS shell and PEG have enhanced biological stability and plasma half-life as well as reduced immunogenicity and tendency to form aggregates (Walling et al.
2009). Only exposure to uncapped CdTe QDs resulted in a concentration-dependent reduction in cell viability (20 nM: $64.6 \pm 7.1, p<0.001 ; 40 \mathrm{nM}: 30.1 \pm 9.7$, $p<0.001 ; 250 \mathrm{nM}: 7.7 \pm 4.3, p<0.001$ ), as compared to PCL-b-PEO, P4VP 21 -b- PEO $_{45}$-gold nanoparticles, $\mathrm{CdSe} / \mathrm{ZnS}$ and $\mathrm{CdSe} / \mathrm{ZnS} / \mathrm{PEG}$ nanoparticles $(<250 \mathrm{nM})$. It is clear that the stability of the QD greatly influences its propensity to cause cellular perturbations.

To investigate the role of glutathione in the adaptive cell response to selected QDs (Table I), the concentrations of intracellular glutathione species were assessed biochemically using the Tietze method (Tietze 1969). Cells were exposed to non-toxic doses of $\mathrm{CdSe} / \mathrm{ZnS}$ and CdTe QDs for $24 \mathrm{~h}$ (250 nM and $4 \mathrm{nM}$, respectively). Exposure to non-toxic CdSe/ZnS QDs did not elicit a significant change in intracellular glutathione species with respect to the control (Figure 1A), nor did low nanomolar concentrations of CdTe QDs (Figure 1B). However, total intracellular glutathione (tGSH) and GSSG concentrations increased progressively in response to increasing concentrations of CdTe QDs, indicated by diamond and triangle symbols respectively ( $\mathrm{tGSH}-20 \mathrm{nM}: 3.7 \pm 0.1 \mathrm{nmoles} / 10^{6}$ cells, $p<0.001$; $40 \mathrm{nM}: 5.6 \pm 0.3 \mathrm{nmoles} / 10^{6}$ cells, $p<0.001$ and GSSG $-20 \mathrm{nM}: 1.34 \pm 0.1, p<0.001 ; 40 \mathrm{nM}: 3.6 \pm$ 0.03 nmoles $/ 10^{6}$ cells, $p<0.001$; Figure $1 \mathrm{~B}$ ).

Having observed global upregulation of intracellular glutathione concentrations in cell lysates, tGSH concentrations were then measured at the level of individual cells using monochlorobimane ( $\mathrm{mCBi}$ ) following exposure to CdTe QDs. mCBi penetrates the cell membrane and reacts specifically with GSH to form a fluorescent adduct (mCBi-GSH) which is readily detected by fluorescent microscopy and spectrofluorimetry (Bragin et al. 2010; Sathishkumar et al. 2010). Fluorescent images of live cells containing the $\mathrm{mCBi}-\mathrm{GSH}$ adduct were acquired following 24-h exposure to CdTe QDs (Figure 2A). Individual cells were then classified as having high, medium or low levels of tGSH based on mean area grey calculations following image analysis using ImageJ software. Under control conditions, the majority of cells contained low tGSH $(92 \pm 4.0 \%)$. A smaller proportion of cells $(7.6 \pm$ $3.2 \%$ ) had medium levels and very few cells were observed to contain high tGSH $(1.2 \pm 2.2 \%)$. The tGSH subpopulation distribution was markedly different following exposure to CdTe QDs. The majority of cells exposed to CdTe QDs contained moderate tGSH levels $(20 \mathrm{nM}: 68 \pm 2.1 \%, p<0.001 ; 40 \mathrm{nM}: 89 \pm$ $5.3 \%, p<0.001)$ while a smaller population exhibited high fluorescence $(20 \mathrm{nM}: 25 \pm 2.6 \%, p<0.001$; $40 \mathrm{nM}: 5.4 \pm 2.3 \%, p<0.05)$. There was a significant decrease in the number of cells within the low population following CdTe QDs treatment with respect to 

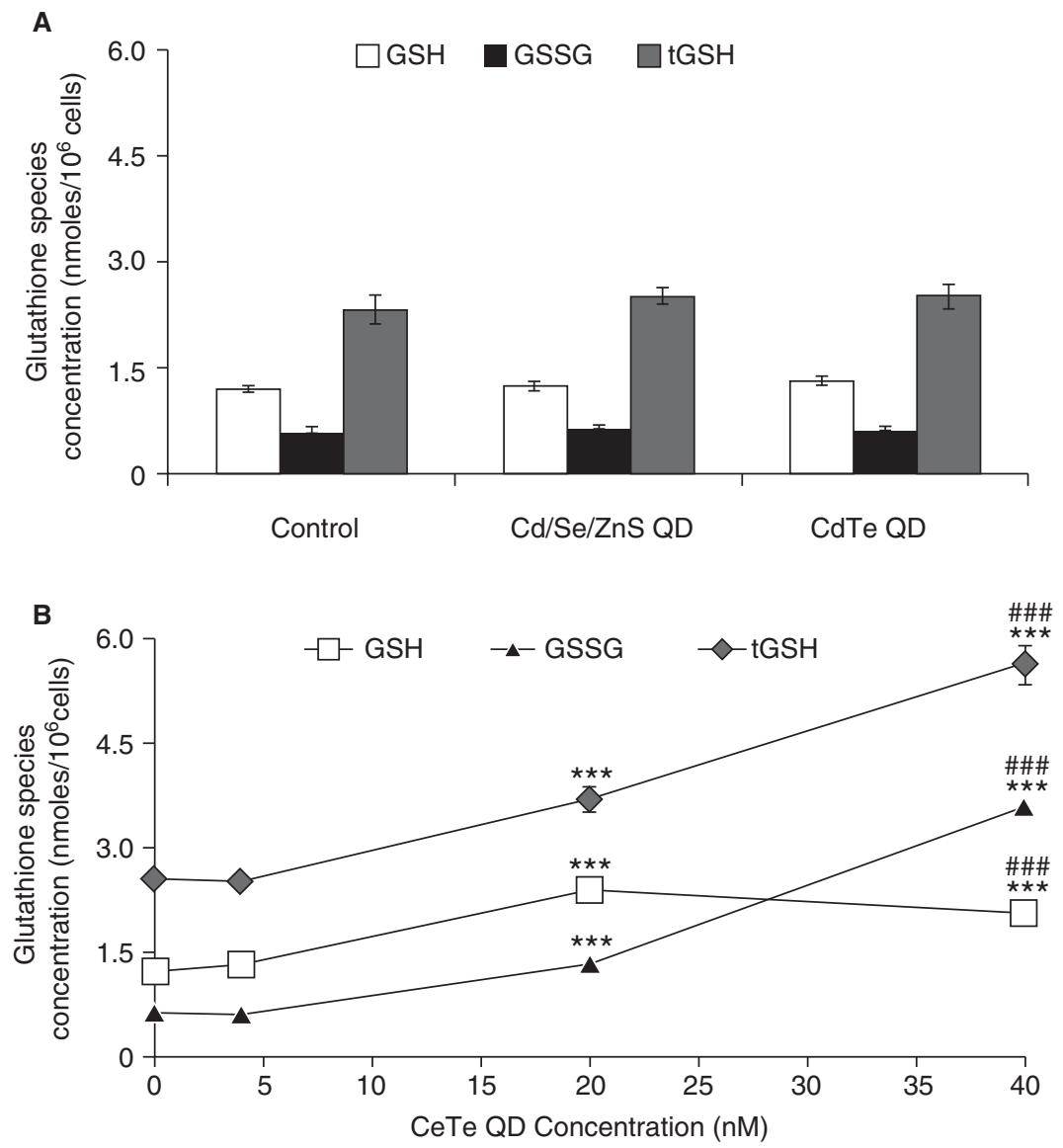

Figure 1. Exposure to toxic concentrations of CdTe QDs enhances total intracellular glutathione. (A) GSH, GSSG and tGSH concentrations were determined in cells exposed to CdSe/ZnS and CdTe QDs (250 and $4 \mathrm{nM}$, respectively; 24 hours). Data are presented as means $\pm \mathrm{SEM}$ of three individual experiments of triplicates. (B) GSH, GSSG and tGSH concentrations were determined in cells exposed to CdTe QDs (0, 4, 20 and $40 \mathrm{nM} ; 24 \mathrm{~h}$ ). Data are presented as means \pm SEM of three individual experiments of triplicates. Statistically significant differences from control were tested with Dunnett's test and indicated by ${ }^{\star \star \star} p<0.001$. Statistically significant differences between 20 and $40 \mathrm{nM}$ CdTe exposure were tested with independent $t$-test and are indicated by $\# \# p 0.001$.

the control and a reciprocal increase in medium and high tGSH subpopulations $(p<0.001)$. Following treatment with lipoic acid, there was a significant increase in the number of both medium $(66 \pm 5.1 \%$, $p<0.001)$ and high $(9.4 \pm 2.1 \%, p<0.01)$ glutathione containing cells. Following exposure to increasing concentrations of CdTe QDs, there was no significant difference in the magnitude of the tGSH changes observed from both the biochemical assay and the spectrofluorometric determination of $\mathrm{mCBi}-$ GSH (Supplementary Figure 3, available online).

The adaptive cellular response to toxic CdTe QDs involves glutathione synthesis

To examine the contribution of glutathione synthesis to the adaptive cell response, we pretreated PC12 cells with both a pharmacological inhibitor and inducer of glutathione synthesis, L-buthionine sulfoximine (BSO) and lipoic acid respectively. Pretreatment with lipoic acid for $24 \mathrm{~h}$ enhanced intracellular glutathione concentrations and significantly reduced CdTe QD induced-toxicity $(87 \pm 2.1 \%, p<0.001 \mathrm{com}$ pared to the control; Figure 2C). Cells were independently pretreated with $50 \mu \mathrm{M}$ BSO, a selective inhibitor of glutathione synthesis (GCL), for $4 \mathrm{~h}$, then concomitantly with CdTe QDs for $24 \mathrm{~h}$. There was a significant decrease in cell viability $(16 \pm 0.3 \%, p<0.001)$ following BSO exposure, compared to CdTe QD treatment alone $(64 \pm 2.0 \%)$.

\section{QD-induced formation of ROS/RNS and activation of $M A P K s$}

Next we examined the involvement of specific ROS or RNS in CdTe QD-induced oxidative stress, and the involvement of specific ROS or RNS and stress response signaling in CdTe-induced oxidative stress. DHE was used to measure superoxide formation in PC12 cells treated with $20 \mathrm{nM}$ CdTe QDs for $4 \mathrm{~h}$ 

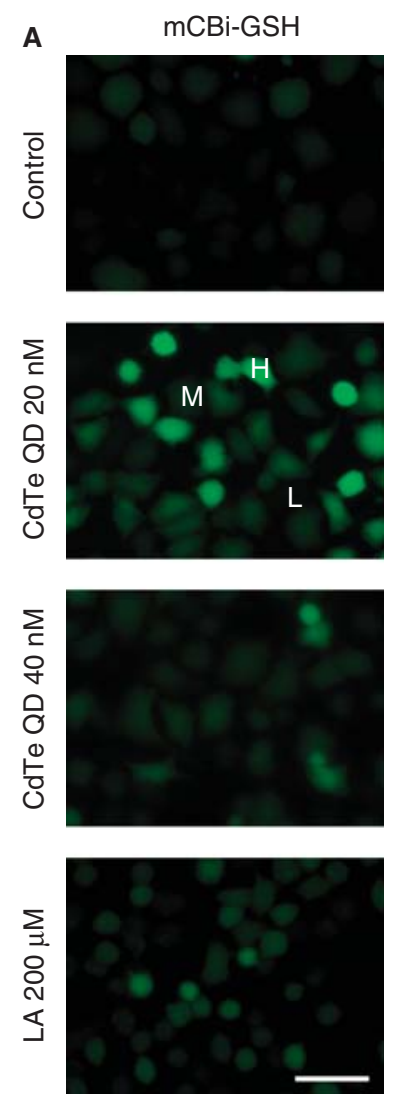

B
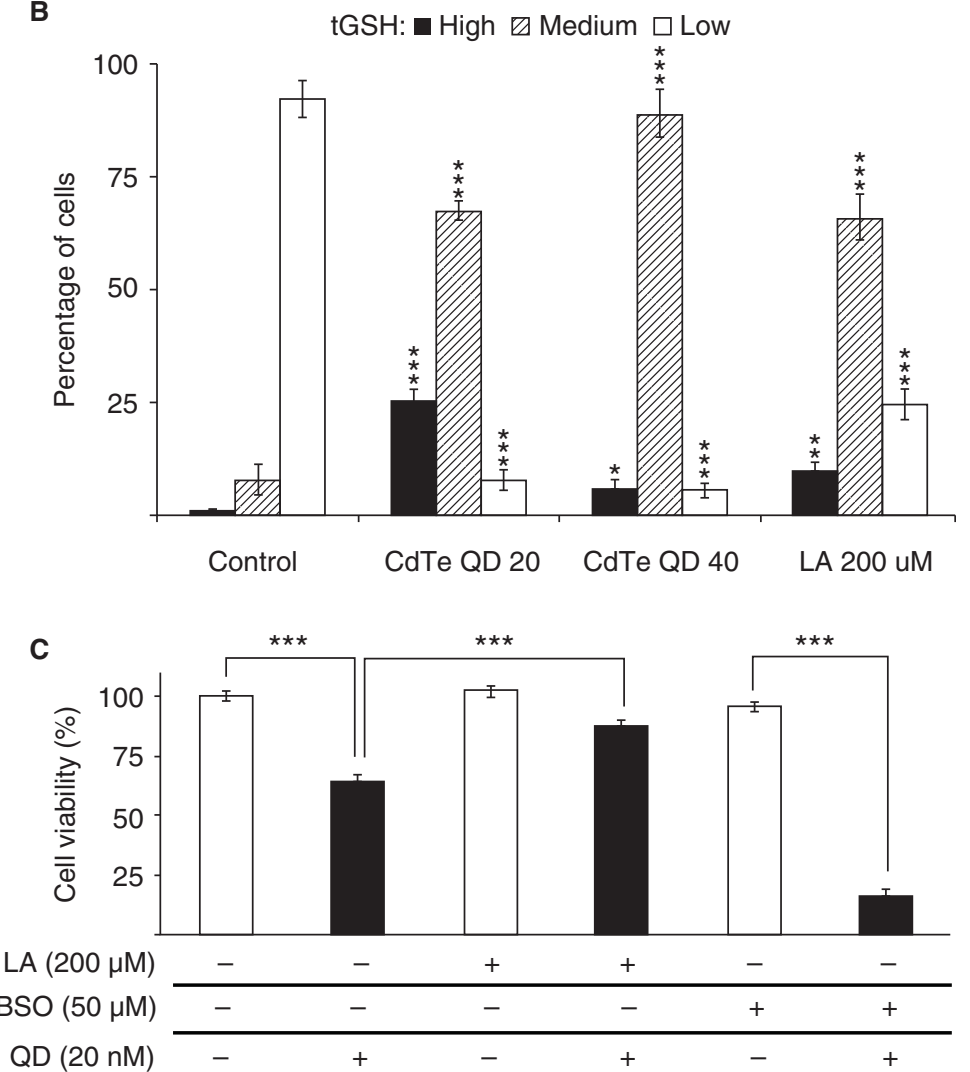

Figure 2. The adaptive cellular response to CdTe QDs involves redistribution of glutathione species and glutathione synthesis. (A) Intracellular glutathione was assessed with $\mathrm{mCBi}(50 \mu \mathrm{M} ; 1$ hour) in cells exposed to CdTe QDs or lipoic acid (20, $40 \mathrm{nM}$ and $200 \mu \mathrm{M}$, respectively; 24 hours). Representative cells are shown, indicating L (low), M (medium) and H (high) total intracellular glutathione. Representative pictures are from at least three independent experiments of triplicates. Scale bars represent $60 \mu \mathrm{m}$. (B) The relative number of cells containing low, medium or high tGSH concentrations of intracellular glutathione was quantified from fluorescent microscopy pictures. Data are presented as means \pm SEM of at least nine individual pictures per condition. Statistically significant differences from the control were tested with Dunnett's test and indicated by ${ }^{\star} p<0.05,{ }^{\star \star} p<0.01,{ }^{\star \star \star} p<0.001$. (C) Cellular viability was assessed in cells exposed to CdTe QDs (20 nM; $24 \mathrm{~h}$ ), following pretreatment with BSO or lipoic acid (BSO: $50 \mu \mathrm{M}, 4 \mathrm{~h} ; \mathrm{LA}: 200 \mu \mathrm{M}, 24 \mathrm{~h}$ ). Data are presented as means \pm SEM of three individual experiments of triplicates. Significance was tested with independent $t$-tests and indicated by ${ }^{\star \star \star} p<0.001$.

(Figure 3A). We observed a significant increase in superoxide formation with respect to control in cells exposed to CdTe QDs $(27 \pm 3.5 \%, p<0.01)$. To evaluate the effects of CdTe QDs on RNS generation, we treated PC12 cells with $20 \mathrm{nM}$ CdTe QDs for $24 \mathrm{~h}$ and assessed nitrosative stress using antibodies against 3-nitrotyrosine (3NT) (Figure 3B). $3 \mathrm{NT}$ is a product of tyrosine nitration mediated by reactive nitrogen species such as peroxynitrite anion and nitrogen dioxide. 3NT levels normalized to cell number were significantly increased in cells exposed to $20 \mathrm{nM} \mathrm{CdTe}$ QDs $(355 \pm 86 \%, p<0.01)$ (Figure 3C). Indeed, CdTe QDs are potent inducers of both ROS and RNS.

The JNK and p38 pathways are activated by the exposure of cells to different kind of stress, including oxidative stress, environmental stress and toxic insults (Su et al. 2008). Early transient activation usually mediates cell survival while prolonged activation is implicated mostly in cell differentiation and apoptosis ( $\mathrm{Li}$ et al. 2002, 2003). We examined the phosphorylation status of stress activated MAPK members JNK and p38 in PC12 cells exposed to $20 \mathrm{nM}$ CdTe QDs (Figure 3D). Quantification of immunoreactive bands from Western blots is shown, indicating significant increase in the extent of phosphorylation for JNK, and p38 in the presence of CdTe QDs, compared to untreated (serum free) control cells. The JNK and p38 pathways were both significantly activated following 4-h treatment with CdTe QDs and the activation persisted up to $24 \mathrm{~h}$ (6-fold increase, $p<0.01$ and 4 -fold increase, $p<0.05$, respectively). The intensity of JNK phosphorylation decreased after $24 \mathrm{~h}$ from the maximal activation at the 4 hour time point. In contrast, activation of p38 in CdTe QD treated cells persisted with the same or even higher intensity at $24 \mathrm{~h}$. 


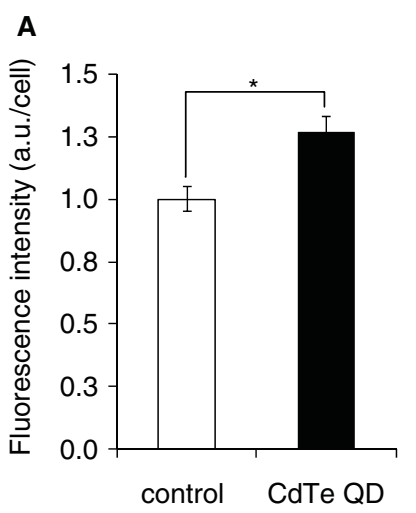

B

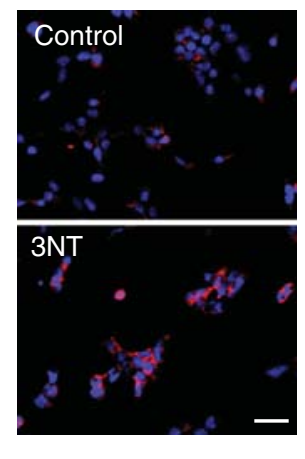

C

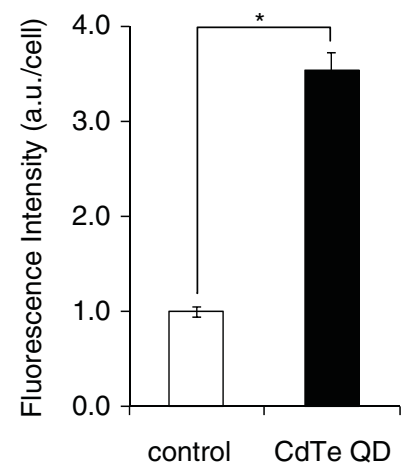

D
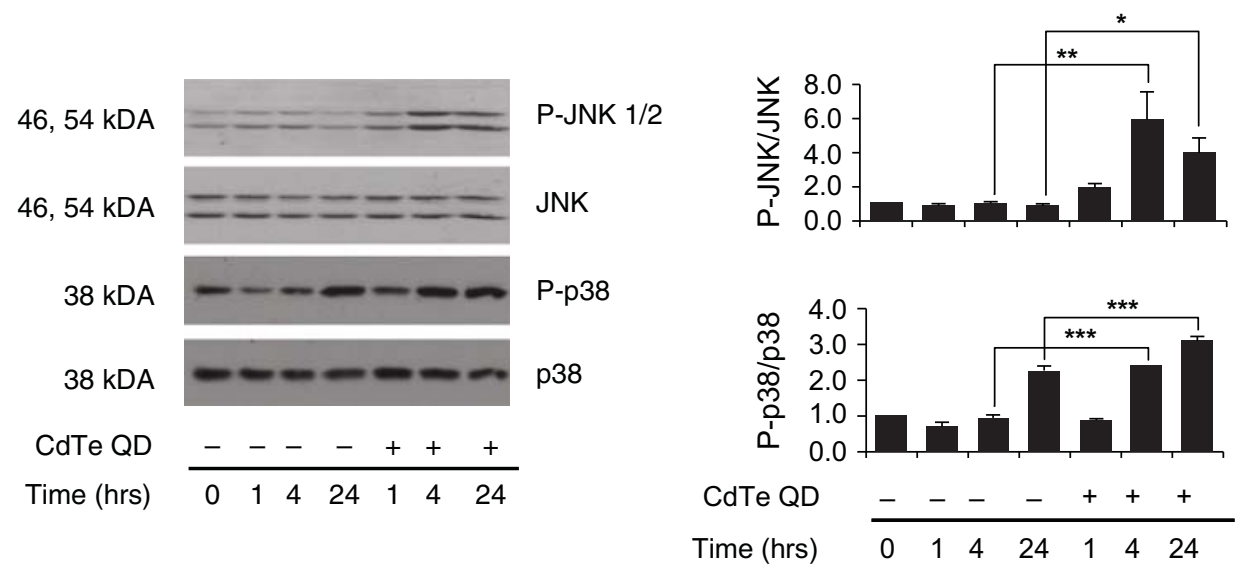

CdTe QD

Time (hrs)

Figure 3. Exposure to CdTe QDs results in the formation of ROS/RNS and activation of MAPKs. (A) The formation of ROS was assessed with DHE (10 $\mu \mathrm{M} ; 30$ minutes) in cells treated with CdTe QDs (20 nM; 4 hours). Data are presented as means \pm SEM of three individual experiments of triplicates. Significance was tested with independent $t$-test and indicated by ${ }^{\star} p<0.05$. (B) Nitrosylated proteins (indicated in red) were labeled using a primary anti-3NT antibody in cells treated with CdTe QDs ( $20 \mathrm{nM} ; 4 \mathrm{~h}$ ). Nuclei (indicated in blue) were labeled with Hoechst (10 $\mu \mathrm{M}, 30$ mintues). Representative pictures are from at least three independent experiments of triplicates. Scale bars represent $80 \mu \mathrm{m}$. (C) 3-NT fluorescence intensity was quantified from representative pictures $(n=9)$. Data are presented as means \pm SEM of three individual experiments of triplicates. Significance was tested with independent $t$-test are indicated by ${ }^{\star \star \star} p<0.001$. (D) Western blot and densitometric values for the phosphorylation of JNK, p38 and cleaved caspase 3 in cells treated with CdTe QDs (20 nM, 1, 4; 24 h). Data are presented as means \pm SEM of three individual experiments of triplicates. Statistically significant differences were tested with independent ttests and are indicated by ${ }^{\star} p<0.05,{ }^{\star \star} p<0.01,{ }^{\star \star \star} p<0.001$.

\section{Exposure to toxic CdTe QDs induces morphological changes in cellular organelles and the activation of TFEB}

We examined the mitochondrial and lysosomal status of PC12 cells following exposure of CdTe QDs using electron and fluorescence microscopy (Figure 4A). Electron micrographs provided evidence for marked morphological changes of mitochondria including deformation, swelling, loss of cristae (black arrows) and the appearance of numerous vacuoles (white arrows). The increased volume of the cellular vacuolar compartment was confirmed in live cells and analyzed using LysoTracker DND-26, a marker of acidic organelles including lysosomes (Figure 4B). There was an apparent time dependant expansion in the total volume of the cellular lysosomal compartment following exposure to CdTe QDs. Total LysoTracker DND-26 fluorescence intensity progressively increased over time, reaching the maximum following 24-h exposure to $20 \mathrm{nM}$ CdTe QDs (3.27 \pm 0.4 -fold, $p<0.005$ ) (Figure 4C). Serum containing media was used for the control as serum withdrawal is a potent inducer of autophagy and lysosomal biogenesis (Stern et al. 2008). Treatment with rapamycin $(200 \mathrm{nM})$, another well characterized inducer of autophagy, significantly increased the fluorescence intensity of acidic compartment measured by lysosomal marker LysoTracker DND-26 (3.01 \pm 0.4-fold, $p<0.001$ ) (Rubinsztein et al. 2007; Stern et al. 2008).

To directly assess the involvement of TFEB activation in the cellular adaptation process, we performed immunocytochemistry to assess lysosome associated membrane protein LAMP1 expression, an indicator of TFEB activation. Treatment with rapamycin and CdTe QDs resulted in a significant 
A
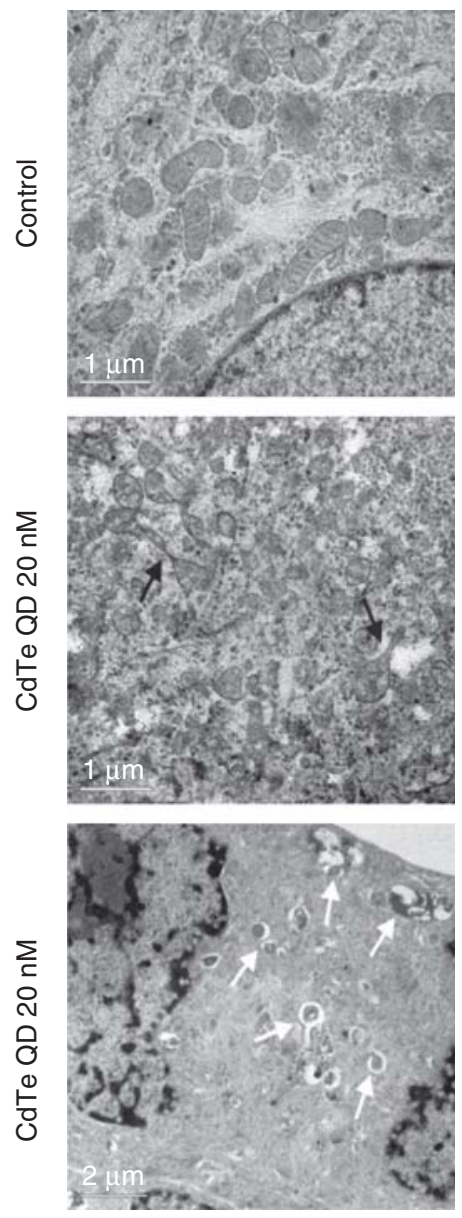

B Control (S+)
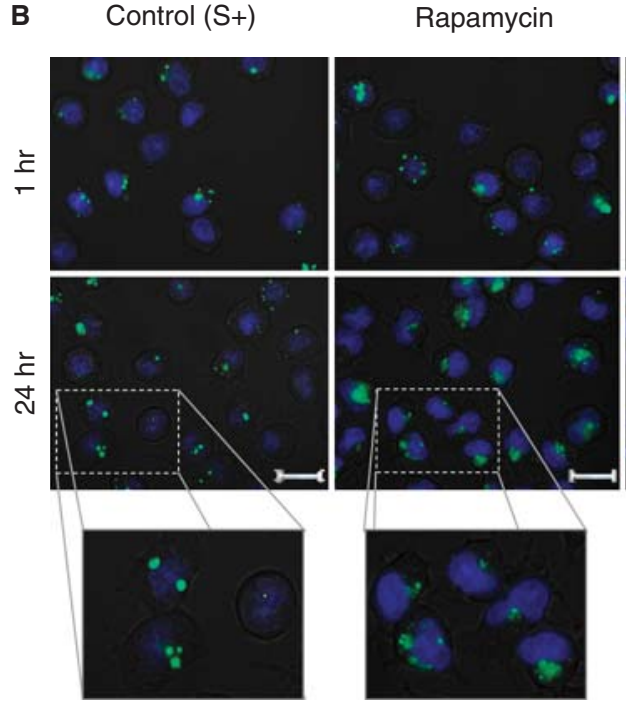

CdTe QD $20 \mathrm{nM}$

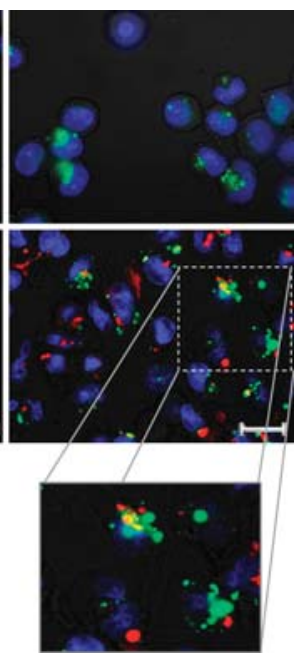

C

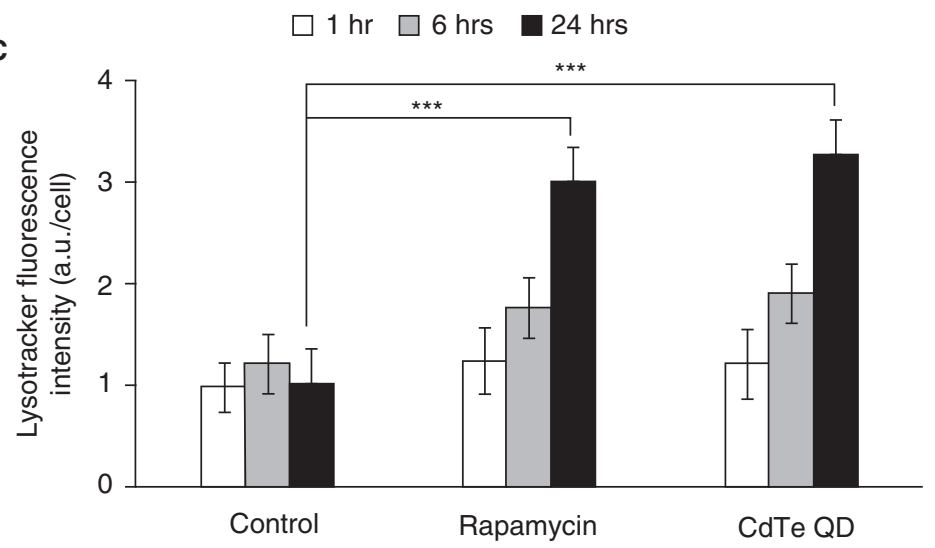

Figure 4. Exposure to CdTe QDs results in dynamic changes in the status of cellular organelles. (A) Electron micrographs showing cells with normal nuclear membrane and mitochondria morphology (controls). Cells treated with CdTe QDs (20 nM; 24 hours) show abnormal mitochondria (black arrows) and increased presence of vacuoles and autophagosomes (white arrows). Representative pictures are from at least three independent experiments of triplicates. (B) Cellular lysosomal content (green) was labeled with LysoTracker Green DND-26 (500 nM; $2 \mathrm{~min}$ ) in cells treated with rapamycin (200 nM) and CdTe QDs (20 nM) for 1, 6 and $24 \mathrm{~h}$. Nuclei (blue) were labeled with Hoechst $(10 \mu \mathrm{M} ; 30 \mathrm{~min})$ and CdTe QDs are visible in red. Representative pictures are from at least three independent experiments of triplicates. Scale bars represent $20 \mu \mathrm{m}$. (C) Intracellular LysoTracker Green DND-26 fluorescence intensity was quantified from fluorescent microscopy pictures. Data are presented as means \pm SEM of three individual experiments of triplicates. Statistically significant differences from the control (untreated cells cultured in serum containing media) were tested by one sample $t$-test are indicated by ${ }^{\star \star \star} p<0.001$.

increase in LAMP1 fluorescence intensity $(200 \mathrm{nM}$ rapamycin: $3.23 \pm 0.6$-fold, $p<0.001 ; 20 \mathrm{nM} \mathrm{CdTe:}$ $5.41 \pm 0.7$-fold, $p<0.001)$ compared to control (Figure 5B). TFEB activation in response to CdTe QD exposure was then evaluated by measuring the degree of translocation from the cytosol to the nucleus, where TFEB directs lysosomal biogenesis. TFEB migrated from a primarily cytosolic localization to a perinuclear localization following 6-h exposure to $20 \mathrm{nM} \mathrm{CdTe}$ (Figure 5C). Quantification of the subcellular localization of TFEB from immunofluorescence micrographs revealed a significant timedependant increase in the nuclear distribution of
TFEB following exposure to CdTe QDs for 1 and $24 \mathrm{~h}(56.2 \pm 3.1 \%, p<0.001 ; 74.9 \pm 4.2 \% p<0.001$, respectively) compared to control (Figure $5 \mathrm{D}$ ).

\section{Discussion}

Eukaryotic cells have acquired a series of compensatory protective mechanisms to adapt to oxidative stress throughout evolution (Dickinson et al. 2003). We investigated two potential cellular adaptation processes and observed significant intracellular changes in both systems following exposure to toxic concentrations of CdTe QDs. We provide evidence for the 
A
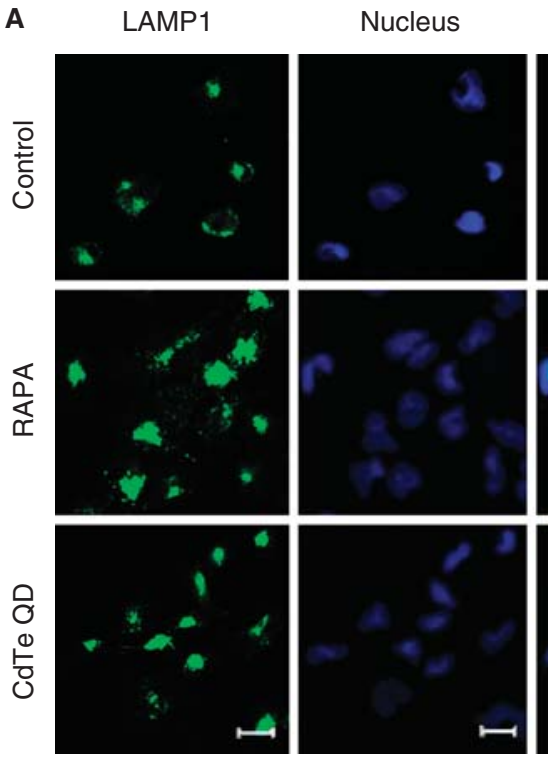

B
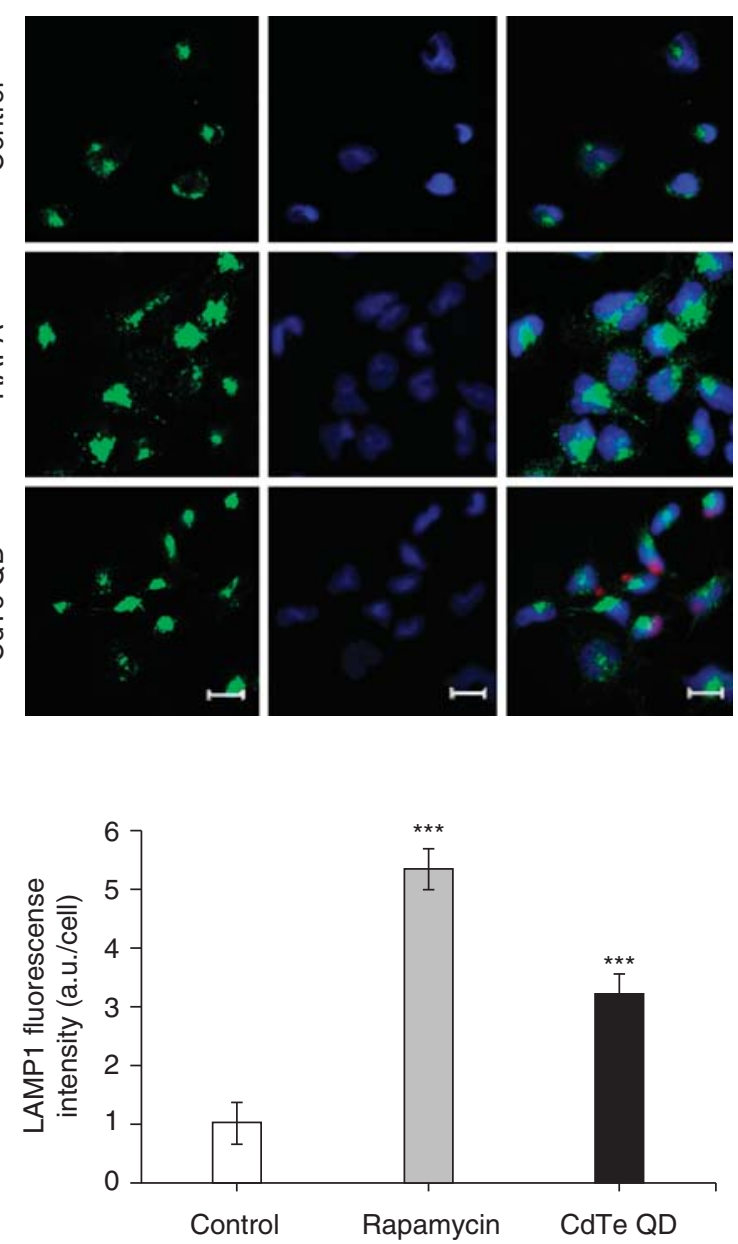

C

TFEB
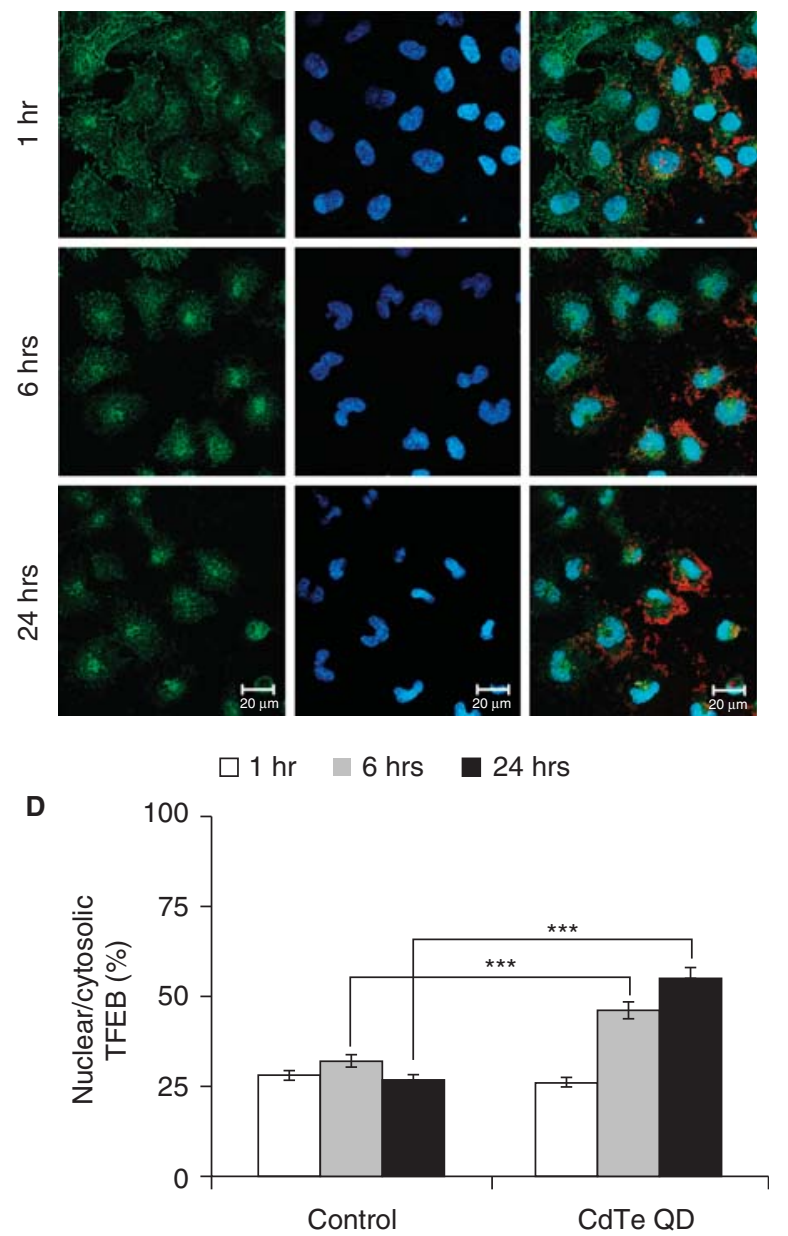

Figure 5. Exposure to CdTe QDs leads to the progressive activation of transcription factor EB. (A) LAMP1 expression (green) was assessed using a primary anti-LAMP1 antibody. Cells were treated with rapamycin $(200 \mathrm{nM})$ and CdTe QDs (20 nM) for 6 hours. Nuclei (blue) were labeled with Hoechst (10 $\mu \mathrm{M} ; 30$ minutes) and CdTe QDs are visible in red. Representative pictures are from at least three independent experiments of triplicates. Scale bars represent $20 \mu \mathrm{m}$. (B) LAMP1 fluorescence intensity was quantified from fluorescent microscopy pictures. Data are presented as means \pm SEM of three individual experiments of triplicates. Statistically significant differences from the control were tested by one sample $t$-test are indicated by ${ }^{\star \star \star} p<0.001$. (C) TFEB subcellular localization (green) was assessed using a primary antiTFEB antibody in cells treated with CdTe QDs $(20 \mathrm{nM})$ for 1,6 and $24 \mathrm{~h}$. Nuclei (blue) were labeled with Hoechst (10 $\mu \mathrm{M} ; 30 \mathrm{~min})$ and CdTe QDs are visible in red. Representative pictures are from at least three independent experiments of triplicates. Scale bars represent $20 \mu \mathrm{m}$. (D) The nuclear/cytosolic TFEB subcellular location was quantified from fluorescent microscopy pictures. Data are presented as means \pm SEM of three individual experiments of triplicates. Statistically significant differences from the control were tested by one sample $t$-test are indicated by $\star \star \star p<0.001$.

involvement of the glutathione antioxidant system in the cell-specific response to QD-induced oxidative stress and propose that TFEB is a key mediator of the underlying adaptive changes observed in the cellular lysosomal compartment.

In nature, cells are exposed to a wide range of noxious stimuli some of which include biological and artificial nano-sized particles. Once endogenous cellular antioxidants are depleted, electrophiles and peroxidized lipids lead to the disruption of redox homeostasis. ROS/RNS can function as signaling molecules through modification of redox sensitive cysteine sulfhydryls which antagonize the inhibition of nuclear-factor-E2-related-factor
(Nrf2) by Keap1 (Chen et al. 2006). This results in the nuclear translocation of NFR2 and expression of enzymes including SOD, CAT and GCL). Nrf2 activation may occur via direct or indirect phosphorylation of Nrf2 itself or regulator proteins by MAPKs (Li and Kong 2009). Activation of MAPKs cascades in response to oxidative stress is well documented; however, the specific molecular mechanisms of Nrf2 activation remain unclear (Piccirillo et al. 2009). One potential mechanism is the phosphorylation of Cul3, a Nrf2 binding protein by MAPKs (Rachakonda et al. 2008). JNK and p38 have been specifically implicated in Nrf2 activation as their 
inhibition has abolished the adaptive response to GSH depletion (Andreadi et al. 2006; Li et al. 2007). We found that $\mathrm{NK}$ and p38 were activated early and intensely after treatment with uncapped CdTe QDs. We propose that QD-induced oxidative stress leads to activation of MAPK kinases, translocation of Nrf2 and activation of tier 2 defenses, facilitating the enhancement of de novo glutathione synthesis.

Glutathione is especially important with respect to QD toxicity as it serves in the first line of defense, due to the formation of highly stable glutathione-cadmium complexes. The cadmium center of these complexes can assume several different coordination geometries with the glutathione molecule, rendering glutathione a highly effective cadmium chelator (Singhal et al. 1987; Belcastro et al. 2009). However, CdTe QD toxicity does not result from the simple addition of cadmium and tellurium components, but rather depends on the unique physicochemical properties of the nanocrystal structure as a sum greater than its parts (Jain et al. 2009). Undifferentiated rat pheochromocytoma cells (PC 12) are an attractive model to study the adaptive cellular response to oxidative stress, because they are well characterized and the signal transduction pathways have been previously described in detail (Greene and Tischler 1976; Kaplan 1998; Patapoutian and Reichardt 2001; Vaudry et al. 2002).

PC 12 cells with low basal tGSH appear to be more sensitive to CdTe QD exposure than those with medium or high tGSH, suggesting that cell survival is due, in part, to increased total glutathione levels. This proposition is supported by the fact that exposure to toxic concentrations of CdTe QDs resulted in a 14-fold decrease in the fraction of cells containing low tGSH and a reciprocal 14-fold decrease in the fraction of cell contacting medium/large tGSH concentrations. We believe that the dramatic shift in the distribution of glutathione subpopulations represents a cell specific adaptation response. The largest increase in the proportion of cells containing high tGSH was measured following exposure to $20 \mathrm{nM}$ CdTe QDs, as opposed to $40 \mathrm{nM} \mathrm{CdTe}$ QD. This difference may be due to excessive CdTe QDinduced oxidative damage at higher QD concentrations that limits the capacity of the cell to synthesize more GSH. Non-toxic CdSe/ZnS QDs did not result in an enhancement of tGSH concentrations whatsoever, or a disruption of the GSH/GSSG ratio, suggesting a specific role for glutathione in the adaptation process to toxic QDs. Taken together, cellular exposure to toxic QDs brings about a dynamic redistribution of intracellular glutathione by selectively (i) killing cells with low GSH concentrations, and (ii) sparing those with medium to high GSH concentrations by enhancing GSH synthesis in the spared population. Our findings agree with recent work investigating QD toxicity in undifferentiated
PC12 cells (Prasad et al. 2010). Differentiated PC12 cells are much more sensitive to QD exposure, with significant ROS generation, degeneration of neuritelike processes and cell death occurring at low nanomolar concentrations (0.5-1 nM) (Kumar et al. 2010).

The generation of oxidative stress has been shown to adversely affect the morphology and function of cellular organelles (Lewinski et al. 2008). Highly metabolically active organelles, such as mitochondria, are particularly sensitive to changes in redox homeostasis (Cheng et al. 2011). Mitochondria depend on cytosolic synthesis and trafficking of glutathione which strongly sensitises the mitochondria to cellular GSH depletion (Hu et al. 2008). Extensive mitochondria membrane damage, observed in TEM microphotographs, has been associated with inefficient ATP production, enhanced formation of ROS and the release of pro-apoptotic factors (Han et al. 2003). In healthy cells, dysfunctional mitochondria are efficiently engulfed by vesicles and trafficked to acidified lysosomes resulting in the controlled degradation and clearance of damaged cellular components (autophagy). Electron and fluorescence microscopy analysis confirmed the presence of enhanced vacuolization and expansion of the lysosomal compartment in PC12 cells exposed to CdTe QDs.

Oxidative stress-resistant cells have been shown to contain increased levels of cholesterol precursors (lathosterol and lenosterol) and cholesterol which accumulates in lysosomes as well as increased cellular sphingomyosin (Clement et al. 2009). Lysosome-associated membrane protein 1 (LAMP1), observed to be upregulated in response to toxic concentration of CdTe QDs, has also found to be enriched in stress-resistant cells, presumably by stabilizing the integrity of the lysosomal membrane and protecting it from oxidation (Butler and Bahr 2006). Additionally, heat shock protein 70 (HSP 70) has been shown to prevent cell death by inhibiting permeabilization of lysosome membranes (Kirkegaard et al. 2010). Indeed, exposure to CdTe QDs results in the enhanced expression of HSP 70 in primary fish hepatocytes (Gagné et al. 2008). As such, cellular adaptation processes serve to mitigate ROS/ RNS species, thus preserving the function of the lysosome, linking autophagy with antioxidant based adaptation mechanisms (Figure 6). It has been suggested that the induction of autophagy may be the direct result of interactions between NPs and the endosome/lysosome or alternatively, NPs may be recognized as an endosomal pathogens and targeted to the autophagy pathway for degradation (Stern et al. 2008). The accumulation of damaged proteins and organelles (particularly mitochondria) following nanoparticle-induced oxidative stress may also account for the observed induction of autophagy. 


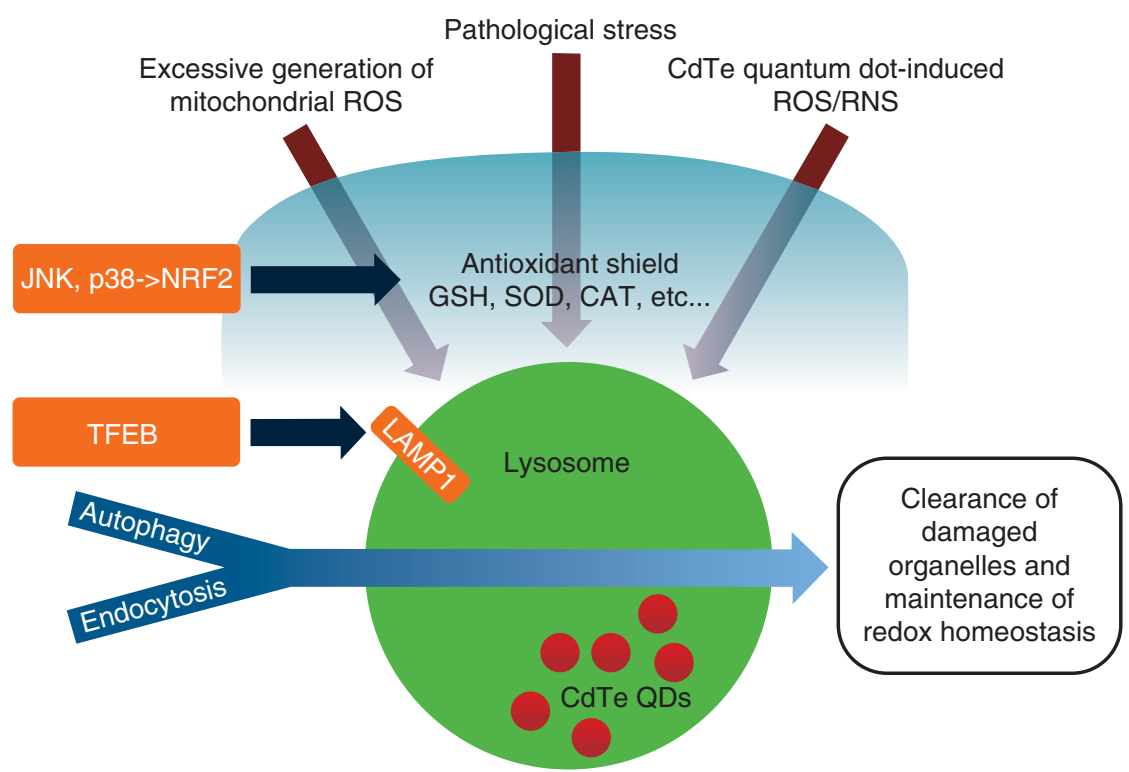

Figure 6. Schematic outlining the proposed interactions between the antioxidant and lysosomal adaptive cellular response to oxidative stress. Activation of MAPKs leads to the expression of antioxidant genes and the strengthening of the antioxidant shield, which serves to maintain redox homeostasis. Activation of TFEB leads to enhanced formation and stability of lysosomes, essential for autophagy and endocytosis function. Together, these processes contribute to the adaptive cellular response to oxidative stress.

Our results implicate TFEB as a mediator of the adaptive response to uncapped CdTe QDs, a proposal supported by: (i) significantly increased fluorescence of lysosomal marker Lysotracker DND 26, (ii) upregulation of LAMP1 expression, and (iii) progressive translocation of TFEB to the nucleus. We believe that the functional outcome of TFEB activation involves the clearance of damaged cellular organelles, particularly mitochondria. Future studies are required to provide direct evidence for the functional dependence of TFEB activation. The precise function and composition of lysosomes following nanoparticle-induced oxidative stress should be further investigated by time course microscopy in cells expressing lysosomespecific proteins (LAMP1/2, Rab7 and CD63) tagged with green fluorescent protein (GFP) family members and proteomic analysis in the presence and absence of TFEB siRNA. Detailed studies employing these approaches may reveal novel lysosome/nanoparticle interactions and elucidate their role in the adaptive cell response to various biological and synthetic nanosized particles. Investigations of these interactions are required to better understand how different morphological, physical and chemical properties of nanoparticles direct cellular fate.

\section{Acknowledgements}

We thank H. Vali and members of the Facility for Electron Microscopy Research (FEMR) for assisting with electron microscopy, Alexandre Moquin for the synthesis and characterization of the CdTe QDs, Anja Kretzshmar for help with preliminary TFEB translocation experiments and Jasmina Lovrić for help with Western blotting.

Declaration of interest: The authors report no conflict of interest. The authors alone are responsible for the content and writing of the paper.

\section{References}

Andreadi CK, Howells LM, Atherfold PA, Manson MM. 2006. Involvement of Nrf2, p38, B-Raf, and nuclear factor-kappaB, but not phosphatidylinositol 3-kinase, in induction of hemeoxygenase- 1 by dietary polyphenols. Mol Pharmacol 69 (3):1033-1040.

Behrendt M, Sandros MG, McKinney RA, McDonald K, Przybytkowski E, Tabrizian M, Maysinger D. 2009. Imaging and organelle distribution of fluorescent $\mathrm{InGaP} / \mathrm{ZnS}$ nanoparticles in glial cells. Nanomedicine (Lond) 4(7):747-761.

Belcastro M, Marino T, Russo N, Toscano M. 2009. The role of glutathione in cadmium ion detoxification: Coordination modes and binding properties - a density functional study. J Inorg Biochem 103(1):50-57.

Biswas SK, Rahman I. 2008. Environmental toxicity, redox signaling and lung inflammation: The role of glutathione. Mol Aspects Med 30:60-76.

Bragin DE, Zhou B, Ramamoorthy P, Muller WS, Connor JA, Shi H. 2010. Differential changes of glutathione levels in astrocytes and neurons in ischemic brains by two-photon imaging. J Cereb Blood Flow Metab 30(4):734-738.

Butler D, Bahr BA. 2006. Oxidative stress and lysosomes: CNSrelated consequences and implications for lysosomal 
enhancement strategies and induction of autophagy. Antioxid Redox Signal 8(1-2):185-196.

Chen ZH, Yoshida Y, Saito Y, Sekine A, Noguchi N, Niki E. 2006. Induction of adaptive response and enhancement of PC12 cell tolerance by 7 -hydroxycholesterol and 15 -deoxy-delta $(12,14)$ prostaglandin $\mathrm{J} 2$ through up-regulation of cellular glutathione via different mechanisms. J Biol Chem 281(20):14440-14445.

Cheng X, Siow RC, Mann GE. 2011. Impaired redox signaling and antioxidant gene expression in endothelial cells in diabetes: A role for mitochondria and the Nrf2-Keap1 defense pathway. Antioxid Redox Signal 14(3): 469-487.

Cho SJ, Maysinger D, Jain M, Roder B, Hackbarth S, Winnik FM. 2007. Long-term exposure to CdTe quantum dots causes functional impairments in live cells. Langmuir 23 (4):1974-1980

Choi AO, Brown SE, Szyf M, Maysinger D. 2008. Quantum dot-induced epigenetic and genotoxic changes in human breast cancer cells. J Mol Med 86(3):291-302.

Choi AO, Cho SJ, Desbarats J, Lovric J, Maysinger D. 2007. Quantum dot-induced cell death involves Fas upregulation and lipid peroxidation in human neuroblastoma cells. J Nanobiotechnol 5:1.

Clement AB, Gamerdinger M, Tamboli IY, Lutjohann D, Walter J, Greeve I, Gimpl G, Behl C. 2009. Adaptation of neuronal cells to chronic oxidative stress is associated with altered cholesterol and sphingolipid homeostasis and lysosomal function. J Neurochem 111(3):669-682.

D'Autreaux B, Toledano MB. 2007. ROS as signalling molecules: Mechanisms that generate specificity in ROS homeostasis. Nat Rev Mol Cell Biol 8(10):813-824.

Dickinson DA, Moellering DR, Iles KE, Patel RP, Levonen AL, Wigley A, Darley-Usmar VM, Forman HJ. 2003. Cytoprotection against oxidative stress and the regulation of glutathione synthesis. Biol Chem 384(4):527-537.

Dinkova-Kostova AT, Talalay P. 2008. Direct and indirect antioxidant properties of inducers of cytoprotective proteins. Mol Nutr Food Res 52(Suppl. 1):S128-138.

Eskelinen EL. 2006. Roles of LAMP-1 and LAMP-2 in lysosome biogenesis and autophagy. Mol Aspects Med 27(5-6):495-502.

Gagné F, Maysinger D, Andre C, Blaise C. 2008. Cytotoxicity of aged cadmium-telluride quantum dots to rainbow trout hepatocytes Nanotoxicology 2(3):8.

Gaponik N, Talapin DV, Rogach AL, Hoppe K, Shevchenko EV, Kornowski A, Eychmuller A, Weller H. 2002. Thiol-capping of CdTe nanocrystals: An alternative to organometallic synthetic routes. J Phys Chem B 106(29):7177-7185.

Greene LA, Tischler AS. 1976. Establishment of a noradrenergic clonal line of rat adrenal pheochromocytoma cells which respond to nerve growth factor. Proc Natl Acad Sci USA 73(7):2424-2428.

Han D, Canali R, Rettori D, Kaplowitz N. 2003. Effect of glutathione depletion on sites and topology of superoxide and hydrogen peroxide production in mitochondria. Mol Pharmacol 64 (5):1136-1144.

Hu J, Dong L, Outten CE. 2008. The redox environment in the mitochondrial intermembrane space is maintained separately from the cytosol and matrix. J Biol Chem 283(43):29126-29134.

Jain MP, Choi AO, Neibert KD, Maysinger D. 2009. Probing and preventing quantum dot-induced cytotoxicity with multimodal alpha-lipoic acid in multiple dimensions of the peripheral nervous system. Nanomed 4(3):277-290.

Janssen-Heininger YM, Mossman BT, Heintz NH, Forman HJ, Kalyanaraman B, Finkel T, Stamler JS, Rhee SG, van der Vliet A. 2008. Redox-based regulation of signal transduction: Principles, pitfalls, and promises. Free Radic Biol Med 45(1):1-17.
Jiang W, Kim BY, Rutka JT, Chan WC. 2008. Nanoparticlemediated cellular response is size-dependent. Nat Nanotechnol 3(3):145-150.

Kaplan DR. 1998. Studying signal transduction in neuronal cells: The Trk/NGF system. Prog Brain Res 117:35-46.

Khatchadourian A, Maysinger D. 2009. Lipid droplets: Their role in nanoparticle-induced oxidative stress. Mol Pharm 6(4): $1125-1137$.

Kirkegaard T, Roth AG, Petersen NH, Mahalka AK, Olsen OD, Moilanen I, Zylicz A, Knudsen J, Sandhoff K, Arenz C, Kinnunen PK, Nylandsted J, Jaattela M. 2010. Hsp70 stabilizes lysosomes and reverts Niemann-Pick disease-associated lysosomal pathology. 2010. Nature 463(7280):549-553.

Kosaka N, McCann TE, Mitsunaga M, Choyke PL, Kobayashi H. 2010. Real-time optical imaging using quantum dot and related nanocrystals. Nanomedicine (Lond) 5(5): 765-776.

Kumar MS, Hyun YT, Woo RS. 2010. Cytotoxic effects of surface-modified quantum dots on neuron-like PC12 cells cultured inside microfluidic devices. BioChip J 4(1):82-88.

Lewinski N, Colvin V, Drezek R. 2008. Cytotoxicity of nanoparticles. Small 4(1):26-49.

Li HY, Wu SY, Shi N. 2007. Transcription factor Nrf2 activation by deltamethrin in PC12 cells: Involvement of ROS. Toxicol Lett 171(1-2):87-98.

Li N, Hao M, Phalen RF, Hinds WC, Nel AE. 2003. Particulate air pollutants and asthma. A paradigm for the role of oxidative stress in PM-induced adverse health effects. Clin Immunol 109 (3):250-265.

Li N, Kim S, Wang M, Froines J, Sioutas C, Nel A. 2002. Use of a stratified oxidative stress model to study the biological effects of ambient concentrated and diesel exhaust particulate matter. Inhal Toxicol 14(5):459-486.

Li N, Xia T, Nel AE. 2008. The role of oxidative stress in ambient particulate matter-induced lung diseases and its implications in the toxicity of engineered nanoparticles. Free Radic Biol Med 44 (9):1689-1699.

Li W, Kong AN. 2009. Molecular mechanisms of Nrf2-mediated antioxidant response. Mol Carcinog 48(2):91-104.

Lovric J, Bazzi HS, Cuie Y, Fortin GR, Winnik FM, Maysinger D. 2005a. Differences in subcellular distribution and toxicity of green and red emitting $\mathrm{CdTe}$ quantum dots. J Mol Med 83(5):377-385.

Lovric J, Cho SJ, Winnik FM, Maysinger D. 2005b. Unmodified cadmium telluride quantum dots induce reactive oxygen species formation leading to multiple organelle damage and cell death. Chem Biol 12(11):1227-1234.

Maher J, Yamamoto M. 2010. The rise of antioxidant signaling the evolution and hormetic actions of Nrf2. Toxicol Appl Pharmacol 244(1):4-15.

Maysinger D. 2007. Nanoparticles and cells: Good companions and doomed partnerships. Org Biomol Chem 5(15):2335-2342.

Nel A, Xia T, Madler L, Li N. 2006. Toxic potential of materials at the nanolevel. Science 311(5761):622-627.

Nel AE, Madler L, Velegol D, Xia T, Hoek EM, Somasundaran P, Klaessig F, Castranova V, Thompson M. 2009. Understanding biophysicochemical interactions at the nano-bio interface. Nat Mater 8(7):543-557.

Packer L, Witt EH, Tritschler HJ. 1995. alpha-Lipoic acid as a biological antioxidant. Free Radic Biol Med 19(2):227-250.

Patapoutian A, Reichardt LF. 2001. Trk receptors: Mediators of neurotrophin action. Curr Opin Neurobiol 11(3):272-280.

Pelley JL, Daar AS, Saner MA. 2009. State of academic knowledge on toxicity and biological fate of quantum dots. Toxicol Sci 112 (2):276-296. 
Piccirillo S, Filomeni G, Brune B, Rotilio G, Ciriolo MR. 2009. Redox mechanisms involved in the selective activation of Nrf2-mediated resistance versus p53-dependent apoptosis in adenocarcinoma cells. J Biol Chem 284(40):27721-27733.

Prasad BR, Nikolskaya N, Connolly D, Smith TJ, Byrne SJ, Gerard VA, Gun'ko YK, Rochev Y. 2010. Long-term exposure of CdTe quantum dots on PC12 cellular activity and the determination of optimum non-toxic concentrations for biological use. J Nanobiotechnol 8:7.

Przybytkowski E, Behrendt M, Dubois D, Maysinger D. 2009. Nanoparticles can induce changes in the intracellular metabolism of lipids without compromising cellular viability. FEBS J 276(21):6204-6217.

Rachakonda G, Xiong Y, Sekhar KR, Stamer SL, Liebler DC, Freeman ML. 2008. Covalent modification at Cys151 dissociates the electrophile sensor Keap1 from the ubiquitin ligase CUL3. Chem Res Toxicol 21(3):705-710.

Rubinsztein DC, Gestwicki JE, Murphy LO, Klionsky DJ. 2007. Potential therapeutic applications of autophagy. Nat Rev Drug Discov 6(4):304-312.

Ruffmann R, Wendel A. 1991. GSH rescue by N-acetylcysteine. Klin Wochenschr 69(18):857-862.

Sardiello M, Palmieri M, di Ronza A, Medina DL, Valenza M, Gennarino VA, Di Malta C, Donaudy F, Embrione V, Polishchuk RS, Banfi S, Parenti G, Cattaneo E, Ballabio A. 2009. A gene network regulating lysosomal biogenesis and function. Science 325(5939):473-477.

Sathishkumar K, Gao X, Raghavamenon AC, Murthy SN, Kadowitz PJ, Uppu RM. 2010. Determination of glutathione, mitochondrial transmembrane potential, and cytotoxicity in $\mathrm{H} 9 \mathrm{c} 2$ cardiomyoblasts exposed to reactive oxygen and nitrogen species. Methods Mol Biol 610:51-61.

Savic R, Luo L, Eisenberg A, Maysinger D. 2003. Micellar nanocontainers distribute to defined cytoplasmic organelles. Science 300(5619):615-618.
Sidorov SN, Bronstein LM, Kabachii YA, Valetsky PM, Soo PL, Maysinger D, Eisenberg A. 2004. Influence of metalation on the morphologies of poly(ethylene oxide)-block-poly(4-vinylpyridine) block copolymer micelles. Langmuir 20(9): 3543-3550.

Simakova O, Arispe NJ. 2007. The cell-selective neurotoxicity of the Alzheimer's Abeta peptide is determined by surface phosphatidylserine and cytosolic ATP levels. Membrane binding is required for Abeta toxicity. J Neurosci 27(50):13719-13729.

Singhal RK, Anderson ME, Meister A. 1987. Glutathione, a first line of defense against cadmium toxicity. FASEB J 1(3): 220-223.

Soo PL, Sidorov SN, Mui J, Bronstein LM, Vali H, Eisenberg A, Maysinger D. 2007. Gold-labeled block copolymer micelles reveal gold aggregates at multiple subcellular sites. Langmuir 23(9):4830-4836.

Stern ST, Zolnik BS, McLeland CB, Clogston J, Zheng J, McNeil SE. 2008. Induction of autophagy in porcine kidney cells by quantum dots: A common cellular response to nanomaterials? Toxicol Sci 106(1):140-152.

Su QJ, Chen XW, Chen ZB, Sun SG. 2008. Involvement of ERK1/ 2 and p38 MAPK in up-regulation of 14-3-3 protein induced by hydrogen peroxide preconditioning in PC12 cells. Neurosci Bull 24(4):244-250.

Tietze F. 1969. Enzymic method for quantitative determination of nanogram amounts of total and oxidized glutathione: Applications to mammalian blood and other tissues. Anal Biochem 27 (3):502-522.

Vaudry D, Stork PJ, Lazarovici P, Eiden LE. 2002. Signaling pathways for PC12 cell differentiation: Making the right connections. Science 296(5573):1648-1649.

Verma A, Stellacci F. 2009. Effect of surface properties on nanoparticle-cell interactions. Small 6(1):12-21.

Walling MA, Novak JA, Shepard JR. 2009. Quantum dots for live cell and in vivo imaging. Int J Mol Sci 10(2):441-491.

\section{Supplementary material available online}

\section{Supplementary Figure 1-3}

